\title{
The Role of the Family in Traditional Judaism
}

\author{
Luciana Pepi
}

As in many cultures, so in Judaism, the family has a role of central importance; it is the fundamental nucleus of society. The family is a micro-society where one learns: rules, values, ideals, and it is that nucleus which constitutes and gives form to society, giving to the latter its components, its profound values. The rules belonging to society, the relationships which are set up and developed in it, should be the same as those of the family. The centrality of ethics, the basic pivot of Jewish thought of all times (from the biblical teaching onwards) permeates every aspect of family and social life. Within the family, each has a specific role, and respect for individual responsibilities brings about the realisation of a common project. It is in the family that one learns the capacity of relationship, love, respect (respect for the rules, for every individual, for nature), the taking care of the other, mutual understanding, the capacity of listening and all those values and sentiments which enable human life to have meaning and to be lived to the full. In this context, the importance of the role of the parents as educators is clear. Education in the Jewish tradition is conceived as the total, comprehensive formation of the individual. Education includes the complex of values, ideals and knowledge, the strictly cultural aspect. Religious teaching has the central role: the transmission of religious knowledge. The parents must teach the history of the Jewish people; they must set the children on the road to the knowledge of the foundational texts of the tradition, and in first place: Torah, ${ }^{1}$ Mishnah, ${ }^{2}$

1 Often the term Torah indicates the entire Hebrew Bible even if it more accurately designates the five books of the Pentateuch. It is usually translated by "Law", but one has to remember that it derives from the verb yarah (root $y r h$ ) which means to teach, to show, to lay the foundations. The Torah is teaching par excellence. It teaches, in fact, how to live in the right way. The Torah is law insofar as it gives norms for life, contains all God's commandments and prohibitions. The Torah is a gift which sanctifies human life: In giving to man his "law", God teaches him to live in a holy way (Lev 19,2: "Be holy for I am holy"). " ... the Torah is the teaching which God gives to his people, it is the privileged way that leads to him. It teaches man how to live rightly. The Torah puts forward a way of life, not a set of beliefs in definite doctrines. The Torah is also the history of the Jewish people which incarnates for the whole of humanity the difficult path of man to God and towards a life more worthy of being lived" (CAGIATI, Settanta domande sull'ebraismo, 17).

2 In the Jewish tradition, alongside the written Torah there developed the oral Torah (= oral tradition). The written Torah, in fact, precisely because of its complexity, is in need of 
Talmud. ${ }^{3}$ Moreover, after the destruction of the Second Temple (AD 70), the fulcrum of religious life is centred in the family, each house becoming a little temple. ${ }^{4}$ The Jewish tradition privileges the domestic liturgy over

a commentary, a study, to be understood. Hence, alongside the written Torah there arises the oral Torah: explanation and amplification of the written text. "Written law-oral law appear as two different forms of the same revelation: the 'word' demands constant vigilance; otherwise it is forgotten or altered or even disappears. Alongisde his daily study, the Jew has guaranteed this safeguard," PuEcH, Storia dell'ebraismo, 187. In the course of time, part of the oral tradition was put into writing, codified first in the Mishnah, then in the Talmud. The Mishnah was redacted between the I and the III centuries A.D. The term mishnah derives from the verb shanah (root $s n h$ ) which means to repeat, in that only frequent repetition allows what has been taught to become firmly fixed in the memory. It is a codification of laws, traditions and exegeses of the biblical text. The Mishnah too, in its turn, was the object of further study and comment, the result being the Gemara (completion). The combination of Mishnah and Gemara forms the Talmud.

3 Two redactions of the Talmud exist: that of Jerusalem (or the Palestinian) was finished towards the end of the IV century A.D., and that of Babylon (school of Sura), which is more extensive and more structured, was completed in the VI sec. A.D. The Talmud, a text that is very varied and complex, contains: moral and philosophical reflections, narratives, legends, scientific observations, juridical discussions, religious themes (from daily worship to human relationships), exegeses of Scripture. The term talmud derives from the verb lamad to study (root $l m d$ ) and means literally study. With regard to the structure, it is important to note that all the exegeses, as indeed all the laws, are expounded not in a definitive way but so as to conserve their vitality. Often the subjects are expounded under the form of discussions. As Lattes observes: "The Talmud presents us not only with the laws but with all the modifications which the laws have undergone in the various centuries and all the opinions of the ancient doctors on them," cf. LATTES, Aspetti e problemi dell'ebraismo, 294. One cannot fully understand Jewish thought - in all its forms - if one does not grasp the constant reference of Jewish thinkers, of all times and places, to the Torah and the Talmud. Both the Torah and the Talmud need continuous study, unceasing commentary; there will always be new and different interpretations. In order to remain something living and adapted to the ever new needs of those who read it, the Torah has need of new and different exegesis. Tradition has the task of holding together all the different exegeses and interpretations. There is no one interpretation superior to another; all are valid. As a rabbinic maxim declares, "the Torah has seventy faces."

4 According to the rabbis, the house which the couple builds is like a little sanctuary (Mikdash me'at). The term derives from the tradition according to which, after the destruction of the Jerusalem Temple, its holiness was transferred to the Jewish house. Whoever enters a Jewish house will notice a series of distinctive characteristics: on the right door jamb, there hangs a small and elegant box, the Mezuzah. It contains passages of the Torah written on parchment, taking up the text of Deut 6,9 according to which "these precepts which I shall give you today ... you will write them on the doorposts of your house and on your gates." Another important place in the Jewish house is the kitchen in which the need to keep meat and milk products in separate dishes and pans, implies, usually, the existence of more than one cupboard and two wash basins. In preparing their home, the spouses are encouraged to leave a small part of the house 'incomplete' (a part of the wall, for example, is left unpainted), in order to recall that without the Temple, Jewish life remains incomplete. 
that of the synagogue and the culminating moment of the celebration of almost all the religious feasts takes place in the family. ${ }^{5}$

From the rabbinic point of view, as we shall see later, the Torah is the fount of all knowledge, of all understanding. The Torah teaches how to live; it contains potentially all teaching necessary for the realisation of man as man. By their example, the parents must witness to their faith and teach concretely how to live rightly. The realisation of a life lived in the correct way, in conformity with the divine will, following the norms of the Torah, enables the human being to realize his original likeness to the Creator. To realise the image and likeness which each individual bears within himself implies, also, the capacity to set up true and deep relationships within the family. In this sense, the family relationships between husband and wife, between parents and children must be conformed to those between the creature and his Creator.

As a result, rabbinic exegesis underlines the value of the biblical teaching: the account of the creation of man in the image and likeness of God (Gen 1:27), of the creation of the woman from the rib of the man (Gen 2:22-24), and all the biblical verses which describe the relationship between God and the human being as that of a parent with his son take on foundational value. Both the verses of Gen 1:27 and those of Gen 2:2224 witness to an original unity which, in the Jewish perspective is the basis for the concept of marriage. The love which should bind together the members of the people as a whole is the reflection of the love which binds together the members of the family, who, in turn, are founded on the nuptial love. And this nuptial love is the very breath of divine love. ${ }^{6}$ In this connection, the multiple exegeses of the well-known verse "Therefore a man shall leave his father and his mother and cleave to his wife, and the two shall become one flesh" turn out to be significant. ${ }^{7}$ In the traditional rabbinic exegesis, the expression "the two shall become one flesh" is understood as a total transformation. From that moment, that person who was an individual formed out of soul and body, no longer is such and is transformed into a complex social reality. ${ }^{8}$ The value of

5 Cf. Hayoun, La liturgia ebraica; Di SAnte, La preghiera di Israele; MunK, Il Mondo delle preghiere; CATtANi (ED.), LA PREghiERA QUOTIDIANA di IsRaele; HeINEMANN, La preghiera ebraica, JACOBS, La preghiera chassidica.

6 Cf. Moscati, Il matrimonio nella dottrina rabbinica,10-11.

7 In his Commentary on Genesis 2:24,Rashi writes: "the baby is formed through both the parents, and it is in him that they become one sole flesh." RASHI DI TROYES, Commento alla Genesi, 22.

8 Moscati, Il matrimonio nella dottrina rabbinica, 20. 
marriage $e^{9}$ is founded on the same originally divine creation: "male and female he created them." The first family has its origin in the primordial couple. Israel Moscati observes: “We find written in Genesis 1:27-28: 'So God created man in his own image, in the image of God he created him; male and female he created them. And God blessed them, and God said to them, Increase (Be fruitful) and multiply, and fill the earth.' From these verses we learn that God himself created the first nuclear family, with the supreme aim of producing children..."10

There are three commands which indicate the mission of the life of man: increase, and that is be open to a life that is more extended; multiply, and that is procreate, bearing in this procreation the divine blessing; and fill the earth, that is fill what has been created with His blessing through our presence. ${ }^{11}$ Every human being is the image and likeness of God. Each new life, therefore, is an increasing of this image on this earth. Many Jewish medieval exegetes, Yaqov Anatoli for example, observes that whoever does not procreate it is as if he would not increase the image of God. ${ }^{12}$

Humanity is one because at the beginning there is the indissoluble union of the first human couple. Humanity is one because belonging to the human family. The parental relationship is wonderfully expounded in the biblical text and especially in the tenth chapter of Genesis where humanity is described as linked by threads of different generations, beginning from Noah: "These are the families of the sons of Noah, according to their genealogies, in their nations; and from these the nations spread abroad on the earth after the flood" (Gen 10:32). ${ }^{13}$ As Elena Loewental affirms, each member of the people is bound to the other like the link on

9 The relationship of love between the spouses is "in the image", of the love between the human being and his Creator. It is significant that rabbinic exegesis adapts the wellknown passage Hos 2:21-22 "and you will be bound to me for ever, and you will be bound to me in justice and righteousness, with love and with mercy. And you will be bound to me with faithfulness and you will know the Lord," which refers to the relationship between the human being and his Creator, to the faithfulness between the spouses. Just as the bond between man and God requires: eternity, justice, right, love, mercy and fidelity, so also that between the spouses.

10 Moscati, Il matrimonio nella dottrina rabbinica, 25.

11 Ibid., 13.

12 Yaqov Anatoli, philosopher, exegete, Jew from Provence, was also a doctor and translator at the court of the Emperor Frederick II. Cf. J. AnAToli, Il pungolo dei discepoli, 99.

13 In order to understand better this chain which links each new member to its distant ancestors, it seems to me interesting to recall that among the various nuptial benedictions, the officiant recites "... may this man and wife be blessed as he blessed Adam and Eve, ... Abraham and Sarah, Isaac and Rebecca. Cf. MoscatI, Il matrimonio nella dottrina rabbinica, 17 . 
a chain. ${ }^{14}$ The genealogies, as we know, have considerable importance in the biblical narrative and in Jewish life. It is no accident that the Hebrew term toledot, used to indicate history, signifies literally 'generations.'

Since God is the first and unique parent, it follows that there is a link of fraternity among all human beings. As the prophet declares: "Have we not all one father? Has not one God created us?" (Mal 2:10). ${ }^{15}$ There is, therefore, a peculiar link among all human beings as brothers (in so far as they are sons of the one Father), just as there is a peculiar bond between spouses (inasmuch as they are united ontologically in their primordial creation).

The bond which unites a man to his own wife, marriage, is defined by the masters of the Talmud with the term qiddushim (sanctification). This holiness has the aim of creating a new generation founded on love to-

14 Loewental, L'ebraismo, 22-23, in explaining the link between each Jew of today and his distant ancestor, describes a chain which links each individual to his father, Abraham. She writes thus: "Jewish continuity is exactly like a chain, and the people of Israel is represented thus: a chain in which each one of us is none other than a tiny link. Without that link, however, the chain is broken. This small link which each one of us is, is truly connected to the one which precedes it, and is attached to the one which follows. Thus, from generation to generation, since in Hebrew in order to say 'history' one uses a word that is feminine plural, which actually means 'generations,' toledot, which is usually translated with 'history.'

15 An appellative that occurs frequently both in Jewish prayers and in traditional texts such as the Mishnah and the Talmud is precisely "Our Father who art in heaven" ('Avinu shebeshamaijm). God is Father insofar as he is Creator and insofar as he takes care of his creatures. Very significant, in this respect some verses from the Old Testament, for example Isa 63:15-16 "Do not be forced into heard-heartedness, for you are our Father ... You, O Lord, are our Father ('Avinu)." In the Psalms and in the book of Jeremiah, we also find the expression 'My Father': "He will call me: you are my Father ('Avi), my God and my rock of salvation" (Ps 89:27). In the synagogal prayers, we encounter the expression 'Our Father' ('Avinu ) in various texts. For example, in the benediction with title With great love ('Ahavah rabbah), which precedes the recital of the Shema' Israel (Hear O Israel), the most important Jewish prayer. The benediction goes thus: "With great love you have loved us, O Lord our God, ... our Father ('Avinu ), our King ... Father, merciful and compassionate, have mercy on us ... ." We find the expression 'Our Father' also in the prayer of the Shemoneh 'esreh (Eighteen Benedictions), which follows the Shema' Israel. Three times the invocation is renewed "Our Father" ('Avinu), in the fifth, sixth and last benediction respectively: "Turn us, our Father, to your law"; "Pardon us, our Father, we have sinned"; "our Father, bless us all as one with the light of your countenance." Here we have a greater affinity with the Christian Paternoster, an affinity yet more evident in another well-known prayer, the Qaddish, which goes thus: "Magnified and hallowed be his great name, in the world which he has created according to his will; his Kingdom come during our life and in our days and during the life of the whole house of Israel, soon and in the approaching time. Amen ... Let the prayer of the whole house of Israel be received before their Father who is in heaven". Cf. BIANCHI, Il padre nostro, Milano 2010. 
wards the one God and the observance of his commandments. As is said in Leviticus, the duty of every human being is to become holy, as the Lord is holy: "Be ye therefore holy, as I the Lord your God am holy" (Lev 19:2). For the Jew, this is absolutely the most important biblical commandment. Only with the observing of the mitzvot ${ }^{16}$ is it possible to become holy, distinct, and so to realise the will of the Lord. The family is the first place in which one learns the path towards holiness. Very fine in this respect are the pages of Moses Maimonides ${ }^{17}$ for whom the imitatio dei is the way which leads to that perfection which is possible for the human being. The perfection of man consists in his becoming like God. ${ }^{18}$ The becoming like God, the actuating of the original likeness, coincides with the becoming holy. The verbal root qds from which the term qadosh derives has multiple meanings. It indicates: to separate, consecrate, be new, be cleaned, be full, be perfect. Very significant is the exegesis of Rashi who understands the term qadosh in the meaning of to be distinct, different. ${ }^{19}$

In this place, it is a pleasure for me to recall the explanation proposed by Dante Lattes in his most beautiful book, Aspects and Problems of Judaism:20 "To be holy does not mean denying oneself, does not imply asceticism, but signifies the fulfilment of the responsibilities belonging to humanity and the observing of customs which are a limit, an exercise, but not a renunciation. Thus, the image of God in potentiality in man becomes the image of God in fact; the likeness to God, that is intellectu-

16 The Hebrew word mitzwah is a good rendering of the relation between precept, obligation and commandment. The verb from which it dervives: siwwah, means, in fact, to command, ordain, establish, constitute, give instructions. The commandment is a divine obligation, and, as such, renders daily life, profane and mortal as it is, permeated with a sense of the divine and the immortal. By practising the mitzwot, the Jew makes his own life full, realises himself, his own humanity, a humanity that is a yearning straining for the divine.

17 Born in Cordoba in 1138, Moses Maimonides, is the most famous philosopher, jurist and exegete of medieval humanism. Maimonides' works are numerous. For the bibliography, cf. Leaman, Moses Maimonides; Cerchiai - Rota (eds.), Maimonide e il suo tempo; BenEDETTO, Mosè Maimonide nell'ottavo centenario della morte; ZonTA, Mosè Maimonide.

18 Maimonides, La Guida dei perplessi.

19 In his commentary on Lev 19:2, Rashi's interpretation, which understands the term 'holy' in the sense of 'distinct,' 'differentiated,' 'different,' sees in the words of God not only a justification of difference, but difference as an essential duty. As if to say, "You are different from the other peoples just as I, the Lord, am different from the other gods." This concept of difference as a divine precept to be fulfilled puts up for debate, among other things, that man realises himself only in conformity, in supine subjection to the social code currently in force, always rejecting any singularity. Judaism is a way of individualisation, which exalts the person straining, with constant yearning, for totality.

20 LATtes, Aspetti e problemi dell'ebraismo, 267. 
al capacity, becomes essentially moral perfection. Man becomes qadosh (holy) or aspires to holiness through purity of conduct, seeking to imitate what are called the paths of the Lord... To follow God in his ways or paths means to imitate his attributed: just as God is merciful, be ye also merciful; just as He is beneficent towards me, do thou also likewise ...." This is the imitatio dei, the central theme in Jewish reflection at all periods of history. The way to reach holiness is fulfilment of the mitzvot, the moral, social and religious laws contained in the Torah. ${ }^{21}$

In building a new family, the couple are obliged to witness to and teach holiness. Besides, they are associated with the creative work of God, continuing the divine work of creation. In Jewish tradition, the conjugal union is considered as the ideal state of human beings and the base of society. According to the traditional rabbinic reflection, each human being possesses three parents: the mother, the father and God, who is the parent of both inasmuch as he is the creator of the primordial couple. The image of God is reflected in the faces of the parents. A Talmudic passage recites: "When a man mistreats his own father and his own mother, the Holy and Blessed One says, turning to Himself: 'It is a good thing that I did not dwell in his house because otherwise he would have mistreated me.'”22 The masters emphasise, moreover, that acknowledgement of one's parents encourages acknowledgement of God just as gratitude towards parents feeds gratitude for the bounty that God confers on man. ${ }^{23}$

The fifth commandment is interpreted in this light: "Honour (kaved) thy father and thy mother." ${ }^{24}$ To honour is expressed in Hebrew by the verb kaved. The root kvd refers to various meanings: beyond to honour, to glorify, it can mean to give weight, to give importance. To honour one's parents signifies in the first place to give them just importance; to recognise their role; to treat them in a quite different way from any other human being. ${ }^{25}$

21 Many philosophers and exegetes, including Maimonides and Anatoli, point out that the Torah has a double aim: the ethical perfection of man, attained by giving norms for right living, and intellectual perfection, attained by giving correct convictions. Cf. ZoNTA, Introduzione a Maimonide. La Guida dei perplessi, 39.

22 B. Qiddushin, $31 \mathrm{~b}$.

23 In the Talmud (Peah 81) one reads "Great is the honour given to father and mother, which the Holy One, blessed be He, has preferred to his own: since, for honouring God, it is said 'Honour the Lord with your riches' (Prov 3), so, if you have them, you are bound, if not, you are exempt. As regards the honour to parents, whether you are rich or whether you are poor, in either case, you have the obligation." Cf. SERMONETA, Grande l'onore verso il padre e la madre, 4.

24 Ex 20:12; Deut 5:16.

25 Kavod means honour, respect, glory, magnificence, splendour. Cf. LARAs, Onora il padre e la madre, 13. 
In the biblical and Talmudic sources, the parental relationship is compared to that particular relationship which is established between the human being and God. That can be deduced from the fact that the Fifth Commandment is part of those regarding the relationship between man and God. In fact, of the Ten Commandments inscribed on two tables, the first five concern the man-God relationship while the last five are directed to the relationship of human beings among themselves. The Fifth Commandment is part of the first five. Marc-Alain Ouakin writes: "For all the Talmudic commentaries, the commandment to honour father and mother forms part of the first category of commandments, those which concern the relationship between man and God. To honour one's parents is a way of honouring God." ${ }^{26}$ Through their union, parents give life and, in a certain sense, are comparable to God. The human capacity to procreate is seen in a certain way as a repetition of the divine action. According to the rabbinic law, parents have the duty of imparting to their children an education imprinted with the value contained in the Torah. Children, on their part, are obliged to respect their parents and this teaching. Since Jewish teaching is based essentially on oral transmission through the education of new generations, respect for the parent is, in a certain sense, the key stone of this tradition, tradition which goes back to the patriarch Abraham. Moreover, in none of the Ten Commandments other than this do we find explicitly expressed the reward for the one who obeys. As it is written: "Honour thy father and thy mother, that they days may be long in the land which the Lord thy God giveth thee." It is the only precept to which is attached a promise, a reward. In fact, the verse holds out length of life on earth or each person as a consequence of the fulfilment of this commandment.

According to some Jewish teachers, including Moshe ben Nachman, medieval exegete and philosopher, the reward to which the verse alludes refers to both the earthly life and the world to come. ${ }^{27}$ Moses Maimonides explains that with the Fourth Commandment God completes the description of the obligations of man to honour the Creator directly. Now God indicates our obligations towards His creatures, beginning with the duties towards parents who are like the Creator in that they are cooperators with God in the creation of a baby. It is as if God were the first parent, and the father and mother complete the task of bringing the one to

In his Guida dei perplessi, Moses Maimonides states that the term that the term kavod, referring to God, indicates his essence (Guida dei perplessi, I, 54; 64).

26 M.-A. OuaKIn, Le dieci parole, 114.

27 Known as Nachmanides (1194-1270). In LARAs, Onora il padre e la madre, 27-28 
be born to the light. For this reason, the repetition of the Commandments (Deut 5:16), after the affirmation "Honour thy father and thy mother," adds a clause: "as the Lord thy God has commanded thee" (kaasher ziwwekhà haShem 'Elohèkha). Just as the Lord has given commandments about His own honour, so he has indicated the duty to honour those who have shared with him in the creation of children..$^{28}$ This explains why the commandment was written on the first table together with the commandments relating to the honour of God. ${ }^{29}$ Rabbinic exegesis explains that the second clause which was added in the second verse, "as the Lord thy God has commanded thee" is intended to give the mitzwah a clearer perspective. It is possible that someone could honour his parents simply out of affection or on account of the moral obligations due to them. The Torah underlines that the individual should fulfil this mitzwah in spite of his personal sentiments or his sensibility. This commandment is not different from any other; it is obligatory because the Lord thy God hath commanded thee.

Further confirmation of the value of this precept is given in a passage from the Mishnah which states thus: "These are the things of which man enjoys the fruits in this world and which earn capital in the world to come: respect for the father and mother, the works of bounty, peacemaking among people and the study of the law which includes them all. ${ }^{\prime 30}$

As we have indicated, the relations that are established within the family have a foundational value for society. The traditional Jewish interpretation emphasises that Scripture itself presents the family-community dynamic as indispensable for a meaningful witness between the different generations. The witness of faith and the transmission of the cultural and religious tradition is a duty of both the family and the community.

Within the family and by means of the family, the children become aware of belonging to the Jewish community, in the perspective of a way of holiness which sanctifies the community itself and the world, a perspective defined as the 'priestly duty.' That confirms the ministerial role of the parents and the necessary family-community interaction which Scripture attests. ${ }^{31}$

28 OUAKIN, Le dieci parole, 115

29 Very interesting are the pages of Rabbi Laras on the motivation for the particular collocation of the precept. Cf. LARAS, Onora il padre e la madre, 28-32.

30 Peah I, 1.

31 The same goes for the Chritsian community. Cf. BARTOLINI - Conori - DANELli, Narrare giocando, 160 . 
In relation to the role of the family, the (normative) halakhah ${ }^{32}$ itself places significant differences between the duties of the man and the woman.

In his relationship with his children, the father has a precise role: it is he who teaches, who transmits the religious knowledge and tradition. From ancient times, the study ${ }^{33}$ of the Torah by the other traditional texts, pre-eminently the Mishnah and the Talmud, has characterised the Jewish people, and it is important to emphasise that the responsibility in this regard is incumbent primarily on the man. For the man, study is a religious obligation; not so for the woman who can study if she wishes but is not obliged to do so. In the same way, the teaching of the children is an obligation, a mitzwah, for the father. The mother directs the child towards a spiritual life, holds an indirect role in the transmission of the traditional culture; the father, on the other hand, is obliged to teach his children the traditional texts and in the first place the Torah, according to what is written in it. We read, for example, in Deut 6:7: "... and you will teach-repeat them (weshinnantam), ${ }^{34}$ to your sons and you will speak of them (wedibbar$t a$ ) in your house or journeying on the way...."

Both the parents, then have the duty of educating the children, even if in different ways. They have to transmit teachings, values, religious-cultural tradition, and they must teach the children to put into practice the precepts, offering them a model of practical life to follow.

In fact, beyond the theoretical part, teaching requires of the parents practical instruction; it is essential to habituate the children to fulfil their numerous duties, to carry out the halakhah. Teaching is thus transformed into actions, rites, ethics. The mother, by bringing to birth and by means

32 The term Halakah, which literally means 'way.' derives from the verb to travel, to go (= halak), indicates the body of rules which regulate the life of the Jew. Paolo De Benedetti writes: "One must not forget that the precept, and the collection of precepts, are called halakhah, 'way' because they are the way to follow. But where does this way lead? To realise the image and likeness of God which He had in his creative project. Now, in the whole of Scripture, the Jew sees one thing only, albeit a multiple image of God, one sole revelation of 'The One who spoke and the world was made': the revelation of his will. God does not speak about his nature, but about what he wills. All the attributes of himself which he reveals are models which man has to incarnate: mercy, faithfulness, patience etc.": De BenEDETTI, Scrittura e Lettura, 7.

33 Study (limud), which is a commandment, is among the peculiar characteristics of the whole Hebrew tradition. Down the centuries, the study of the traditional texts, Torah, Mishnah, Talmud, has allowed the survival of the Jewish identity, despite the diaspora and the various attempts to annihilate that identity.

34 It is imporant to make clear that both the verb shinnatam, from the root snh, and the following verb dibbarta, from the root $d b r$, are second person masculine, Hebrew having a different inflection for masculine and feminine. 
of actions and deeds, is the first to witness to the link with a specific cultural and religious tradition. The father with the narration, the explanation, transmits the traditional teachings.

The rabbinic tradition recognises a reference to this common duty of the parents, with their own different roles, in a biblical verses: Ex 19:3: "And Moses went up to the mount of God, and God called him out of the mountain, saying, These things shalt thou say (to'mar) to the house of Jacob, and thou shalt report (tagghed) them to the children of Israel. Rabbinic exegesis explains that the two verbs - thou shalt say, to'mar, ${ }^{35}$ and thou shalt report, tagghed ${ }^{36}$ - allude to the two modes for transmitting knowledge, one proper to the man, the other to the woman. Elena Bartolini observes: "Why does the Lord confirm the same concept (say/report) with two apparently synonymous verbs? ... The rabbis explain that here we are not faced with a useless repetition because in Scripture every expression always has a particular sense: therefore, the first verb (say/ to'mar) refers to the woman and to her particular role in the transmission of life and the tradition of the faith, while the second (report/ tagghed) refers to the man, who, together with the woman, is called to witness to the faith of the Fathers educating the new generations to a life in the light of the Torah, that is, of the revealed teaching. It can be said that here there is recognised a kind of narrative and communicative difference which can be referred to the difference between men and women which, in the perspective of a relationship of given reciprocity expresses and witnesses to both the faith and the tradition." ${ }^{137}$

It is necessary to bear in mind that in the Jewish tradition, narrative is a basic component, one that constitutes the fulcrum of culture itself. By narrating, the memory is kept living. The value of 'remember' (root, $z \mathrm{kr}),{ }^{38}$ of causing to be remembered, is fundamental for the formation of successive generations. Scripture itself places a particular accent on the importance of the narrative dimension: you shall repeat $(s n h)$, you shall teach saying $(d b r)$, you shall tell $(n g d)$, you shall report (spr) are the verbs that recur with greater frequency.

35 To'mar is the qal imperfect, second person masculine singular of the root ' $m r$ which signifies, primarily saying, but also planning. It seems to me important to recall that ' $m r$ is the verb of creation, the verbal root which we find in Genesis 1. Like God, the woman has creative power. It is their functions which differentiate men and women. Cf. Di SEGNI, La donna rabbino.

36 Tagghed is the hiphil imperfect, second person masculine singular of the root $n g d$, which indicates telling, recounting.

37 BARTOLINI - CONORI - DANELLI, Narrare giocando, 156-157.

38 The bibliography on this subject is extensive. Cf., especially, Yerushalmi, Zakhor. 
According to explicit biblical prescription, the first teachers are the parents and the first teaching is the narrative: "...that you may tell (tesapper) in the hearing of your son and of your son's son how I have made sport of the Egyptians..." (Ex 10:2). ${ }^{39}$

There are many biblical verses that encourage remembering and telling, Deut 32:7, for example. In the last words of his farewell, Moses exhorts the people: "Remember (zekor) the days of old, consider the years of many generations (the course of history); ask (she'al) your father, and he will show you (weyagghedkà); your elders, and they will tell you (weyo'me$r u) . .$. ." The father who responds to the question of his $\operatorname{son}^{40}$ guarantees the generational nexus of the oral tradition, just as the teacher guarantees the 'chain of reception.'

From narration one learns how to act in the present. The theoretical-conceptual and the practical aspects go together. In fact, it is from the narration that there ought to spring up a 'practical' model to follow. Thus the event, the report, once narration becomes teaching to be put into practice. And here we touch on the heart of Judaism, the intrinsic relation between theory and practice: ${ }^{41}$ theory and practice are inseparable. Piero Stefani observes: "Study divorced from practice becomes sterile, situating itself at the opposite pole from that 'we will do and hearken' (Ex 24:7) which represents the high road of Judaism while practice without study becomes an activity that is emptied of any colour, habitual... study represents perhaps the highest form of memory." ${ }^{42}$ Theoretical knowledge must always be accompanied by practical fulfilment, the capacity to live

39 Cf., also, Ex 13:8; 13:14; Deut 6:20-21.

40 Cf. Ex 12:26-27. Asking, questioning expresses one of the principal ways of searching and so the acquisition of knowledge. Piero Stefan writes: "The proverbial hegemony assumed by the question in the Jewish environment has led straight to the coining of the definition of the Jew as one who answers a question by forming another. Nothing more than questioning distinguishes the mobile character of Jewish thought ... the dialectic way of Jewish proceeding is largely assigned to the ability ot formulate new questions." Cf. STEFANI, Introduzione all'ebraismo, 138; JABES, Il libro delle interrogazioni.

41 From the Jewish perspective, knowledge ought not to be separated from action, from works. On the contrary, true gnoseological 'formation' must result in correct action. The mitzwot do not comprise only practical actions but also theoretical ones. It is interesting to recall that among the commandments is also included the study of the Torah (Talmud Torah). Or perhaps it is better to say that this study constitutes the essence of the life of the Jew who intends to practise the worship of God. The study of the Torah is not considered a means to the acquiring of ideas, but itself constitutes the content of the spiritual life of man. Yehoshua Leibowitz writes: "In order 'to study the Torah' one is meant to learn not only what is written in the Torah, but to think about it, to reflect on it, to interpret it and to draw conclusions from it." LeIBowitz, Lezioni, 43.

42 Stefani, Introduzione all'ebraismo, 136. 
correctly, to carry out good deeds. We read in Pirqé Avot: "Whoever has a culture superior to his works is like a tree with many braches but few roots. When the wind comes, it is uprooted and blown down ... ."43

The family becomes, then, the privileged place of a religious experience, the house a 'sacred space' where, in daily life, every deed becomes the sign of a life lived in the continual drive for holiness. It is in this space that one learns to give thanks for everything, every good one enjoys. Every action fulfilled is recognised as a divine gift. ${ }^{44}$ The family is the place in which the dynamics of communion are rooted and developed. It is the place of a love that is authentic and shared. The family is the privileged place of narration and memory. ${ }^{45}$

Memory has a creative force projected towards the future. It withdraws events from the passage of time. As Elena Bartolini states: "In the biblical witness and the Jewish tradition, the action of remembering is never retrospective, and it has a pedagogic function since the acute awareness of collective experience is a fount of wisdom, an appeal to ethics, to responsibility and to identity." 46

With regard to the Jewish education imparted by the family, I would like to devote attention to some significant peculiarities. In the perspective of traditional Judaism, education is based on the Torah. The Torah constitutes the first and potential source of every teaching, of all kinds of education. And this is because the Torah is considered the fount of all knowledge.

As a well-known rabbinic saying goes: "Turn it over again and again: everything is there. Meditate on it, grow old in it, be consumed by it. Do not ever stray far from it, for there is nothing better for you" (Mishna Avot 5,21). ${ }^{47}$ Commenting on verse 98 of Psalm 119, "Thou through thy

43 Pirqè Avot is a collection of maxims of the masters of the tradition which contain great and precious teachings in simple form. Cf. Pirgè Avot, 34.

44 Bartolini - Conori - Danelli, Narrare giocando, 24. With regard to the term 'house,' it is interesting to note that different medieval Jewish exegetes interpret it as an allegorical symbol of wisdom. Cf. Anatoli, Il pungolo dei discepoli.

45 Ps 78, for example, clearly indicates the importance of the family as the place for the remembering of the faith.

46 BARTOLINI - CONORI - DANELLI, Narrare giocando, 13. Cf. the entire chapter devoted to the family and the remembering of the faith, where it is clearly shown how Scripture itself, in particular in the books of Exodus and Deuteronomy, exhorts parents to be the transmitters of salvation.

47 Mottolese, La Parola-Scrittura, observes: “A saying apparently brief and simple: in reality, as with many rabbinic aphorisms, a great density of meaning shines through it. Thus the Book as the thing of most importance in man's life, to be held as the criterion of orientation, to be searched more deeply without ceasing throughout one's life (it says, in fact: 'Contemplate it, grow old in it, and be consumed by it'). But why and 
commandments hast made me wiser than mine enemies, for they are ever with me," Anatoli observes that if one remains anchored firmly in the Torah and does not serve from its precepts, it will indeed be possible to learn from every man, Jewish or non-Jewish, believer or non-believer. Because: "The torah is complete and perfect and necessary for all. Human wisdom cannot exist without fear of the Lord ... without ethical discipline. No wise man should trust only in wisdom, ignoring the words of the Torah ... therefore, it is said; 'Remove not the ancient landmark' (Prov 22:28) because it is the first and eternal limit of all knowledge." 48 This highly significant passage shows well how human wisdom is founded on the fear of the Lord, on ethical discipline, on the Torah, which, being complete and perfect, is the fount and limit of all possible knowledge.

Rabbinic exegesis, as is well-known, investigates at its roots the relationship wisdom-fear. Commenting on verse 10 of Proverbs 9 - "The fear of the Lord is the beginning of wisdom" - Anatoli takes up again the explanations of the masters and affirms the necessity that fear comes before wisdom: "Fear is called the beginning because it is necessary that it always comes before wisdom." ${ }^{\prime 4}$ And again: "The Torah is for wisdom what the foundation (yesod) is for the palace. Just as the palace without foundations can fall, so wisdom without the Torah can be uncertain." 50 The Torah contains theoretical and practical instruction: it teaches correct

how is this to be done? The first step is decisive: 'Turn it over again and again since everything is there.' 'Everything is there': Scripture has in the first place this universal character, an inclusive and all-embracing span. It is not surprising that this characteristic was developed in certain currents of Jewish mysticism which emphasis the infinity, the infinite profundity of Scripture: its words (even its tiny shades of meaning as we shall see) embrace in themselves the whole of reality including its most hidden and deep dimensions. But classical rabbinic literature too focuses on the idea that the Torah includes the important fundamentals for man of every age, and so it is necessary each time to think and understand. Naturally, this also goes for today. It is enough to think of the banal experience of one who hears a rabbi speak on a certain subject (perhaps a contemporary problem): the point of departure is always a certain passage or verse of the Bible read and re-read in order to find an answer ... In more philosophical terms, we could say that Scripture is the perennial horizon, the foundation and the medium of thinking. There cannot be another beginning to, a metaphysical or rational truth 'beyond' or 'behind' those ancient words: the foundation is precisely the scriptural datum which is literally a divine 'given' insofar as it is the 'gift of the Torah' (mattan Torah). More precisely, the Book has been given to men in its two primary components: as foundational Narrative and as the Law."

48 AnAtoli, Il pungolo dei discepoli, 154.

49 Ibid., 222.

50 Ibid., 203. 
opinions and a correct way of living. It is, therefore, the principal and most complete pedagogic instrument of Judaism..$^{51}$ Exegetes of different periods have emphasised that the Torah, as a whole, has two aims: the perfection of the soul and the perfection of the body. Its goal is to lead man to realise to the full the divine will by means of the observance of his religious duties. For the Jew, in fact, the biblical teaching is the manifestation of the word of God for all the areas of life. ${ }^{52}$

The majority of the precepts aim at discipline both under the social profile (precepts which regulate relations between men) and under the religious profile (precepts which regulate the relationship with God) and in this way seek to fashion a balanced, controlled individual and, consequently, a just society. Jewish 'wisdom' is the practical science of life, shrewdness, discernment, prudence, rectitude of life, astuteness and together it is understanding of the will of God. ${ }^{53}$

In his Guide for the Perplexed, Moses Maimonides several times states: "The end of the Torah is to teach the human being how to reach perfec-

51 Perhaps it is possible in this aspect to see a difference from the Greek paideia. If, on the one hand, the educational process is similar in the two cultures, Greek and Hebrew, understood as the complete formation of the individual (intellectual, moral), in Judaism the source of such formation is one, and it is the Torah. The Torah is the source, beginning, foundation and criterion of knowledge. The learning of the other sciences (philosophy, logic, poetry, rhetoric ... ) does not have a decisive role as in the paideia. Another characteristic aspect of Jewish education is the close relation with the practical sphere which in the paideia is regarded as being of the second order

52 The masters seek to explain that the Law is not an imposition but a way of living better. The Law is made for man. The Most High is close to every human being. He is always on man's side.This is one of the conclusions of the great and complex rabbinic output.

53 For the Jewish believer, wisdom is true good to be 'acquired;' the means to reach it is observance of the Law of God. Wisdom comes from God and aims at God. The fear of the Lord is the school of wisdom, and the beginning of knowledge (Prov 1:7; 9:10; 15:33; Job 28:28; Ps 111:10). At the same time, it is the source and culmination of an understanding that is truly religious, one in which an interpersonal relationship is developed with the God of the Covenant according to a modality through which fear and love come together (Ps 25:12-14; 112; Qoh 12:13). The true sage knows and acknowledges that God alone is truly wises: therefore, he entrusts himself to him, he trusts in him and he depends on him. From this viewpoint, God is the only, great pedagogue of the Jewish people. In the Old Testament, the prototype of the ancient masters is God; education is considered a mission which he has entrusted in turn to the Patriarchs, the Judges, the Kings, the Priests and the Prophets and which receives its force from his authority and sanction. At Sinai, God renews with the Israelites the Covenant which he made with their forefathers, Abraham, Isaac and Jacob, and teaches them laws and special regulations. To obey the Lord is Israel's wisdom. (cf. Deut 4: 1-9): “Keep them and do them: for that will be your wisdom and understanding in the sight of the other peoples. When they hear speak of all these statutes, they will say: 'This great nation is a wise and understanding people!'" (Deut 4:6). 
tion of the body and perfection of the soul. Without perfection of the one, the perfection of the other is impossible, given the inseparability of body and soul. ${ }^{\text {"54 }}$ And again: "The Law of Moses creates the best conditions in which men can live with one another, eliminating injustice and granting a noble and virtuous character so that the inhabitants of the country can live in such a way that each of them reaches his initial perfection and the correct beliefs and opinions with which final perfection is attained. The Torah speaks explicitly of these two perfections and informs us that the end of the whole Law is the attainment of them." 55

From time immemorial, the masters of the tradition have pointed out the educative goal of the Torah. In order to live correctly, to develop his own intellectual and moral potentialities, the human being needs instruction and this instruction is supplied by the Torah. Jaqov Anatoli maintains that the human being can become perfect only thanks to the teaching of the Torah.

In his opinion, the ultimate aim of the Torah is to teach the love of God and the observance of his commandments. The individual who loves God and performs his commandments becomes morally and intellectually perfect: He writes thus: "Since the nature of man is more complex than that of the other animals and has to attain two perfections (that of the body and that of the soul), the perfect Torah teaches the attainment of both. It gives commandments regarding the ethical conduct for rendering the body perfect, and commandments regarding the understanding of the truth to render perfect the soul." ${ }^{\prime 56}$ And again: "The end of man is the attainment of two perfections: the perfection of virtue (shelemut hammidot) and the perfection of the intellect (shelemut hasekel). But given that man is born 'as a wild beast' (Job 11:12), he has need of a guide, a master, to get there." ${ }^{57}$

No one can attain wisdom, perfection on his own, but needs a guide, a master: instruction and study are necessary. It is by means of this study that the Jewish people has succeeded in preserving its own character

54 Cf. Maimonides, La Guida dei perplessi, III,27. It is important to recall, very summarily, that, for the philosopher, the perfection of the body corresponds to health/salvation (Shalom: physical and psychophysical well-being), while the perfection of the soul consists of the acquisition of correct ideas with regard to reality and God.

55 Ibid. In introducing the contents of the Guida dei perplessi, Mauro Zonta observes: "The Torah has a dual purpose: the ethical perfection of man- attained by commanding and forbidding specific actions - and his dianoetic perfection- attained by commanding and forbidding specific opinions."

56 AnAtoli, Il pungolo dei discepoli, 218.

57 Ibid.,103. 
down the centuries. The mitzvah of the Talmud Torah (literally study of the Torah) concerns every Jew, whatever his age, whether or not he has received a religious education in his childhood. ${ }^{58}$ In relation to the rest of the precepts, "the study of the Torah is worth all the others put together." Without study, there is no memory, no knowledge. Anatoli writes: "The commandments of the Torah teach the ways of the Lord, and whoever run in them merit being called his sons, just as everyone who follows the path of his father is called his father's son... the verse 'You are the children of the Lord your God' (Deut 14:1), like other verses of the Torah, means to indicate that being called sons stands in relation to study (limud), to learning the knowledge of God, of his unity, his dominion, his love." ${ }^{59}$

This passage, very important and profound, reveals the connection between study, teaching and the parental relationship ${ }^{60}$. Only with the study of the Torah - by learning what can be known of God: his unity, his governance of the world, his love - is the relationship of sonship established. This is why being called sons is in relation to study.

Among the duties of the family, there is also that of transmitting love for study. As has been seen, this study also includes a 'practical' aspect. The concrete performance of the biblical principles constitutes the leading element of education and of self-education in daily religious practice and in the ambit of family and collective gatherings, linked to the holidays and feasts. So then, the role of experience and of the history of the Jewish people involves an educative function right from the earliest age. As has been seen, the responsibility for the study of the Bible is incumbent primarily on the father but also concerns the mother. ${ }^{61}$

"My son, keep your father's commandment, and forsake not your mother's teaching. Bind them upon your heart always; tie them about

58 Tradition, such as the Talmud, insists on the importance of study and declares that the study of the Torah is a more important mitzwah than saving a life ... than the construction of the Temple ... (B. Meghillah 16b). Maimonides affirms that every Jew, rich or poor, even a beggar, in good health or sick, young or old, is obliged to study the Torah (Yad, Talmud Torah 1:8).

59 ANATOLI, Il pungolo dei discepoli, 120.

60 And also, therefore, the figure of the parent is associated with that of the master. In this connection, I like to recall Philo of Alessandria, according to whom disciples are the sons of the soul.

61 A father who cannot teach his own son personally should commission a master in his place. In reality, beside the teaching of the parents, that of a good master is always fundamental. The teaching of the master ( $r a v)$ is, in fact, of great importance. Tradition attributes to a child's master the same status which it attributes to the parents because to teach the Torah to a child who is not one's own is like giving him life (B. Sanhedrin 19b). 
your neck. When you walk, they will lead you; when you lie down, they will watch over you; and when you awake, they will talk with you. For the commandment is a lamp and the teaching a light, and the reproofs of discipline are the way of life" (Prov 6:20-23). These words summarise the value of the educative function of the parents and emphasises the extent of the conception which Judaism has with regard to personal education, a conception without limits of time and place.

"Hear, O Israel: The LORD our God is one LORD; and you shall love the LORD your God with all your heart, and with all your soul, and with all your might. And these words which I command you this day shall be upon your heart; and you shall teach them diligently to your children, and shall talk of them when you sit in your house, and when you walk by the way, and when you lie down, and when you rise" (Deut 6:4-6).

Rabbinic exegesis underlines how, at the beginning of the Shema', after the affirmation of the unicity of God and of love for him, one passes immediately to the duty of transmitting values, a transmission which is to be constant in time and space. This provision of the Shema' is, in fact, addressed to the parents, the fundamental element of society and first ring in the chain of tradition.

To summarise, the cultural transmission is configured under the form of learning a system of values which finds its principal point of reference in the Torah. By means of practice and study, parents and teachers have the prime responsibility for transmitting this tradition, the complex of acts which express it and give it significance.

The whole of Jewish thought on the family turns around pedagogic concepts regarding the education of children in so far as the transmission of the knowledge of the parents to their children is the very foundation of the Jewish family and is a guarantee for the continuity of the Jewish identity and that of the entire community. All the greatest masters of traditional Jewish thought are agreed in affirming that the principal aim of education consists in the transmitting of fundamental universal values on the basis of a healthy relationship between parents and children.

In conclusion, the constant insistence on the value of the family as a social unit for the propagation of the moral, intellectual and religious values, as well as the significant fact that the Hebrew word for marriage is qiddushin, that is, sanctification, show how the Jewish home is the most vital factor in the survival of Judaism and in the preservation of the Jewish way of life, far more so than the synagogue and the school.

Jewish education, therefore, is to be considered as the study which has the double aim of knowing the Torah and its dictates, and, at the same time, teaching what is learned because knowledge is not a privilege 
of the few, ${ }^{62}$ and because with general education one increases in social and human respect.

In the Talmud (Bavà Batrà, 116a) we read: "There are no better books than children brought up in the Torah." It is worth saying that the written text is not endowed in itself with word or power of action, it is not really alive, because it is through the man who actualizes it, putting it into practice and studying it, that it manifests its vitality. ${ }^{63}$

62 By contrast with what happened in ancient Egypt or among the Assiro-Babylonians, among whom education consisted of transmitting knowledge from generation to generation within the privileged classes, Israel knows of a single education - albeit elementary - for all the people without any distinctions of class.

63 Sholem observes acutely: "The Bible is not a monolithic bloc. With the passage of time, man is faced with ever-new problems, and it is necessary to find in the same revealed text the answer to new questions. In every generation, the Torah is interpreted according to the needs of that generation. On the one hand, the Torah is eternal truth, the criterion of all truth, on the other hand, it is not fulfilled except by continuous study, relecture, in every generation ... Until the sages no longer turn to it with their searches, the Torah remains incomplete ... but through their researches, it becomes a completed book." Cf. SHolem, Concetti fondamentali dell'ebraismo, 83-84. 


\section{Bibliography}

ANAToli, J., Il pungolo dei discepoli (Malmad ha talmidim). Il sapere di un ebreo e Federico II. Introduzione, traduzione e note a cura di L. PEPI, 2 voll., Palermo 2004.

Bartolini, E. - Conori , G. -DANelli, E., Narrare giocando, Torino 2003.

BENEDETTO, M., Mosè Maimonide nell'ottavo centenario della morte: un bilancio degli studi e delle prospettive di ricerca, Turnhout 2008 (= Quaestio 4 [2004]).

BianchI, E., Il padre nostro, Milano 2010.

Cagiati, A., Settanta domande sull'ebraismo, Padova 1997.

Cattani, L. (ED.), La PReghiera QuOtidiana di IsRaele, Torino 1990.

Cerchiai, G. - Rota, G. (edd.), Maimonide e il suo tempo, Milano 2007.

De BenEDETTI, P., Scrittura e Lettura nell'ebraismo, in: www.christianismus.it

Di SANTE, C., La preghiera di Israele. Alle origini della liturgia cristiana, Genova ${ }^{2} 1998$.

Di SeGNI, R., La donna rabbino: Zehut, www.morasha.it.

HAYOun, M.-R., La liturgia ebraica, Firenze 1997.

HeinemanN, J., La preghiera ebraica, Magnano ${ }^{2} 1992$.

Jacobs, L. La PReghiera chassidica, Milano 2001.

JABES, E., Il libro delle interrogazioni, Casale Monferrato 1988.

LARAS, G., Onora il padre e la madre, Bologna 2010.

LATTES, D., Aspetti e problemi dell'ebraismo, Roma 1986.

Leaman, O., Moses Maimonides, Richmond 1997.

Leibowitz, Y., Lezioni sulle 'Massime dei padri' e su Maimonide, Firenze 1999.

LoeWENTAL, E., L'ebraismo spiegato ai miei figli, Milano 2002.

Maimonides, M., La Guida dei perplessi, trad. it. a cura di M. ZonTA, Torino 2003.

Moscati, C. I., Il matrimonio nella dottrina rabbinica, Roma 1990.

Mottolese, M., La Parola-Scrittura nel pensiero e nell'esperienza del giudaismo rabbinico: http://morasha.it.

MunK, E., Il Mondo delle preghiere, vol. I: I giorni feriali, Roma 1992.

OuAKIN, M.-A., Le dieci parole. Il decalogo riletto e commentato dai maestri ebrei antichi e moderni, Milano 2001.

Pirqè Avot. Morale di maestri ebrei, Roma 1990.

Puech, H., Storia dell'ebraismo, Bari 1990.

Sermoneta, A., Grande l'onore verso il padre e la madre: Maslulim (1990), pp.

SHolem, G., Concetti fondamentali dell'ebraismo, Genova 1986.

Stefani, P., Introduzione all'ebraismo, Brescia 2004.

Yerushalmi, Y.H., Zakhor. Storia ebraica e memoria ebraica, Parma 1983.

ZonTA, M., Mosè Maimonide, Roma 2011. 